\title{
Determinants of Stock Market Investors' Behavior in COVID-19: A Study on the Pakistan Stock Exchange
}

\author{
Samina Riaz \\ Faculty of Business administration, Iqra University Karachi, Pakistan \\ Riaz Ahmed \\ Faculty of Business administration, Iqra University Karachi, Pakistan \\ Rakesh Parkash \\ Faculty of Business administration, Iqra University Karachi, Pakistan \\ Munawar Javed Ahmad \\ Faculty of Business administration, Iqra University Karachi, Pakistan
}

\begin{abstract}
As one of the most contagious diseases in history, Corona Virus (COVID-19) spread rapidly around the world infecting millions of people in the year 2020. Besides killing huge number of persons, the calamity not only ignited severe panic and chaos among them, it even affected vast businesses and stock markets around the globe. This study was undertaken to investigate those determinants, which affected the extent of stock market investors' behavior in Pakistan during spread of COVID-19. Data was collected from various individual investors, representing a high response rate of about $86.5 \%$ from 167 respondents. From the analysis it was indicated that most important and significantly influencing determinants on investment decisions in Pakistan Stock Markets are pertinent to: 'getting rich quickly, loss aversion, fear of losses, expected corporate earnings and dividends, gut feelings on the economy, previous performances of firm's stock and opinions of its majority shareholders, and eventually, the recommendations of brokers and family/friends. Our findings would first, assist in understanding the most common behavioral patterns of investors and secondly, determine to show the adequate paths, which lead towards the growth of Pakistan Stock Market.
\end{abstract}

Keywords: Investor behavior, herding behavior, stock market, Pakistan.

\section{Introduction}

Initially, the pandemic broke out in the outskirts of China in early January of 2020 and gradually posed severe threats to economies and uncontrollable deaths. Surprisingly, death toll had risen to above millions in the world, still more casualties are being recorded, and obviously forecasting the unexpected deaths to rise even higher in coming days. In attempts to limit the spread of COVID19 , every country was inclined to take various strict and serious measures, like putting an end to daily routine works, seriousness in precautionary methods, suspending almost all, but essential international travelling modes, etc. Their implementation obviously hit all global economies very harshly, and their effects on financial markets were observed in dramatic manner and at much faster speed. Its real overall and actual macroeconomic impacts would come more appropriately 
to the limelight with the passage of time. Major equity markets in the world experienced even more significant decrease up to 50\%. Taking into consideration the shorter and long-run impacts of COVID-19 on economic aspects, many governments instantly announced multi-trillion US Dollars as rescue and safety packages, when its spread started (Seven et al., 2020).

Since stock market plays important role in investors' decision making, it simultaneously improves the efficiency level of Corporate Governance (Samuel, 1996). Many perceptions exist regarding investments in stock markets, as some investors have mere intentions to take control over the firm and become its sole owner; others are inclined towards dividends; whereas another group invests simply for capital gains (Croushore, 2006). Investors usually require specific and major number of shares within a firm to acquire set positions in the board of directors, providing opportunities to participate fully in major decision making aspects, even in uncertain and risky situations (Aziz \& Khan, 2016). The traditional finance theories, such as "Efficient Market Hypothesis", argues that proper information on various investment prospects are equally accessible for investors and explained with clarity accordingly, in normal and feasible manner. Usually stock markets show uncertainty, and investors flock together on similar actions undertaken by others, making investment plans simply based on decisions and actions of other contemporary investors (Fernandez et al., 2011; Mohammad \& Shahar, 2019).

The Pakistan Stock Exchange (PSX) came into being with the integration of three existing stock exchanges from Islamabad, Lahore and Karachi, on $11^{\text {th }}$ January 2016, and became an integrated component of MSCI Emerging Market Index, in May 2017. Currently, 400 brokerage houses along with 21 assets managing companies are registered members of PSX (Anjum, 2020). Pakistan's equity market gradually expanded at a compound annual growth rate of more than $11 \%$ (in terms of US\$) since 1992. Recognized as the most valuable index of PSX, KSE 100 index now includes almost all the largest companies, based on their market capitalization of nearly $85 \%$, representing a good number of all sectors existing in PSX.

The last two decades most impressively showed reliable gauge to measure the market's performance, when the KSE-100 index frequently provided more than $40 \%$ of annual returns. However, second half of the outgoing decade presented a very dismal story of negative returns. The government had to apply the brakes on economic growth in line with the conditions set under a $\$ 6$ billion IMF bailout program, signed and executed recently. After initial sufferings, conditions started to change and apparently came under control in first nine months of this fiscal year, when inflation slowed down and current account deficit decreased by $75 \%$, with timely cut in central bank's interest rates (Balooch, 2020).

The Corona Virus epidemic, first detected in China in December, 2019 gripped the world trade and affected equity markets throughout the world. Pakistan also confirmed the first two cases of Corona Virus on $26^{\text {th }}$ February, 2020, and from then on Pakistan Stock Exchange lost 2,266 points and its equity of 436 billion was wiped out and the market capital stood at Rs. 7,095 trillion during that week, recorded to be at Rs. 7,531, a week before. The foreigners proved to be the biggest sellers of stock worth $\$ 22.5$ million. By the end of February, 2020 their stock amounting to $\$ 56.40 \mathrm{~m}$ were sold. We relate huge selling by foreigners and sharp decline in Index with global sentiments in equity markets as concerns on global outbreak of COVID-19 (Kazmi, 2020). The already sluggish economy came to a grinding halt and complete stand still during the last two months. After lockdown in the country trade suspensions had to be chosen and Pakistan's 
exports declined sharply and flow of remittances also fell down. Almost every business was shut down and factories faced a complete closure, resulting in significant dips, without government's tax revenue. Pakistan's economy had seen a contraction aspect for the first time in 68 years with GDP growth recorded at $-0.4 \%$ in first nine months. Neither agriculture nor industries or services sectors could meet their growth targets. Various analysts pointed out towards the incentives given to the real estate sector in the federal budget. They threatened as a severe warning that investors may pull out of the equity market and invest their booty in real estate to acquire minimum benefits from it (Balooch, 2020).

The government initiated some specific decisions and action plans, including the reduction in interest by 100 basis points (bps), as an attempt to boost up the morale of investors and businessmen. The Monetary Policy Committee (MPC) of State Bank of Pakistan (SBP) decided to reduce the policy rate of 100 bps by $7 \%$, reflecting its views on inflation's outlook to have improved to some extent, whereas local economic reduction still continued and growth in risks also increased. The meeting of MPC was held on $25^{\text {th }}$ June 2020, Against this viewpoint of receding risks in inflation, priority of existing monetary policy had to be shifted towards support the employment factor and growth aspects in appropriate manner, during these critical scenarios and challenging period. The MPC remained consistent with its mandate and had to re-assert its earlier commitment to support households and businesses in minimizing the damages to the economy, throughout the crises period (Kazmi, 2020). The present study is the result of our motivation to examine the factors influencing investors' decisions to invest in stock market during COVID-19. Moreover, this paper is timely, relevant and feasible, as recent damages and crisis in the capital market require careful management and proper handling, so that further destabilization to the economy may not occur.

\section{Literature Review}

Since 'Behavioral Finance' very closely merges both market phenomenon and individual investor's behavior to use knowledge acquired from financial theories and psychological field. The "investors' behavior" is therefore, included to be a part of behavioral finance to explore the implications of systematic financial market within the process of psychological decisions. Moreover, behavioral factors, which influence the decision-making aspects of investors are categorized into following four groups: (1) heuristic theory, (2) prospect theory, (3) market factors, and (4) herding effect. All theories within the group are a reflection of the overall picture showing that behavioral factors place a significant impact on investors' decisions particularly, in stock exchange. Therefore, as a clear indication that all these four theories could be used to recognize and identify the behavior of individual investors and/or even institutional investors in secured trading, irrespective of any type (frontier, emerging or developed) of stock markets (Fromlet, 2001; Ngoc, 2014).

\section{Heuristic theory}

Since the "rules of thumb" is a phenomenon that tends to make decision making simpler and easier, particularly in complex cases and in uncertain conditions, so as to specially provide some definition to the 'Heuristic Theory' (Ritter, 2003). The process of reducing such complexities through probabilities of assessing and simple judgments to forecast the values are part of this theory (Kahneman \& Tversky, 1979). In general conditions, particularly in limited time periods, 
heuristic effects are useful (Waweru et al., 2008). On the other hand, some researchers attempted to prove that heuristic effects often lead to biasness (Kahneman \& Tversky, 1979; Waweru et al., 2008). It is historically assumed that Kahneman and Tversky (1979) are considered to be the first writers on the subject, studied three more vital factors, which were termed as: representativeness, availability bias, and anchoring, were included in the heuristic theory. Two more additional factors, named as 'Over-confidence' and 'Gambler's fallacy' were enlisted by Waweru et al. (2008) to become part of the heuristic theory.

It is firmly believed that 'Overconfidence' improves persistence, mental facilities, determination, and tolerance of any risks. To be more precise, it helps in promoting professional efficiency and performance, besides enhancing perception and abilities of others in boosting up to achieve speedy promotions and more investment durations (Oberlechner \& Osler, 2004). For example, when an investor intends to overestimate his capabilities to acquire proper knowledge to get well acquainted with data on hand, the earlier predictions could be considered as underestimated. Therefore, when any person tends to overestimate the precision and accuracy of his own informative signals instead of going with public informative signals is very rightly defined as 'overconfident investor' (Daniel et al., 1998). Such types of people are inclined to think that their decisions, and they themselves are better than what they actually are, and in real terms are called 'overconfident investor' (Trivers, 1991). In psychology literature and recent finance theories, behavior of such people is termed to be "overconfident". Some more researches explored that overconfidence in human behavior stands as the main and foremost contributing determinant, which leads to phenomenal overtrading within financial market by investors. Barber and Odean (2001) contributed to argue that trading at higher volumes could be attributable to the investors' overconfidence, and often regret their own earlier judgments and decisions as not comparable with assessments of others.

\section{Prospect theory}

The 'Prospect Theory', initially developed by Kahneman and Tversky (1979), very rightly stated that: "We have an irrational tendency to be less willing to gamble with profits than with losses", whereas, Tvede (1999) opposed this theory since it tends to show natural human behavior when investors are almost underway to face risks, ambiguity and insecurity. As a matter of fact, most people are more prone to certainties and therefore, confide on outcomes that are apparently perceived to be more secure. Investors intend to incline towards risks and face losses, whereas those who experience profit and gains are usually exposed to upcoming risks. Human beings do not consistently adjust to risk-aversion, intend to be risk-takers in losses and are risk-averse in gains only (Kishore, 2004). The dependence on structured choices, either in terms of gains or in terms of losses, people respond differently in both cases (Tversky \& Kahneman,1981).

There are two approaches pertaining to decisions to be undertaken by investors. The first is "Prospect Theory", whereas the second is termed as "Expected Utility Theory (EUT)" and both are observed from different angles and taken in appropriate perspectives. The former apparently throws light on subjective decision-making of investors, whereas the latter focuses to concentrate on quite reasonable and normal expectations (Filbeck, Hatfield \& Horvath, 2005). The Prospect theory and EUT differ from each other in many ways with considerate importance. Firstly, in Prospect theory, value maximization functions a pure 'value', and in EUT, it is termed as a 'utility' (Plous, 1993). In other words, in Prospect theory, wealth maximization is taken as exact values, 
which occur between profits and losses, whereas it is referred to be the final wealth position in EUT. Moreover, wealth function is generally concave and tends to be less steep for profits, but steeper and convex for any losses (Kahneman \& Tversky,1979). As noted interestingly by Plous (1993) that though wealth functions for losses may be steeper than for profits, and may apparently be larger, but prove to be 'equal in value'. The significant importance of the differences in Prospect Theory and EUT lead to several noteworthy and remarkable results. Since EUT is considered as standardized model of balanced choices and economic behavior's expressive model as well, it controls the analysis and results of decision making under risks. The critics well criticized this theory since it failed to explain the reasons why people seemed more inclined towards insurance and, attracted towards gambling with keen interest. Mostly people under-weigh outcomes with uncertainty and probabilities in comparison with certain and secure outcomes and are inclined to response in different manners within similar environment, in the context of profits or losses (Kahneman \& Tversky, 1979).

On the other hand, the Prospect Theory describes the state of mind that affects any individual's decision-making aspect, so as to include: (i) Regret aversion, (ii) Loss aversion, and (iii) Mental accounting (Waweru et al., 2003). Loss aversion refers to various levels of mental shocks and penalties that people bear from similar volumes of gains and losses (Barberis \& Huang, 2001). There are ample evidences to show that people feel more distressed and upset on the prospects of losses as compared to parallel profits (Barberis \& Thaler, 2003). Any losses being faced after adequate gains earlier, proves to be less agonizing than a loss coming after a loss (Barberis \& Huang, 2001). Again, Lehenkari and Perttunen (2004) argued that when negative and positive returns in previous cases tend to serve as a source of boosting negative trend among selling factors and capital losses for investors. Hence, it is suggestive that investors are more inclined towards loss aversion. The risks averting variable, considered as normal behavior of investors, tend to bring faulty repercussions on their wealth, so as to affect any of their inappropriate decisions (Odean, 1998).

\section{Market factors}

Since the market factors are considered as external factors which influence investors' behavior, are generally not included in behavioral determinants. DeBondt and Thaler (1995) stated in their study that investors' behavior could seriously affect financial markets through behavioral finance. If its perspectives are correct and precise, then it has to be obviously believed that investors may tend to indicate the following aspects accordingly: some sort of reactions are shown on the changing of prices or even on its news; past trends are extrapolated into the future; focus on popular stocks; ignorance in the fundamental aspects underlying stocks; and seasonal price cycles. The process of decision making by investors in stock market are influenced by these market factors. Waweru et al. (2008) also identified some other market factors, impacting the decision making of investors, as follows: price changes, over-reaction towards changing price, adequate information about market conditions, customer's preferences, fundamental aspects underlying stocks; and, past trends prevalent in stock markets. The changes in market information, stock price, and fundamentals of underlying stock could normally be determined as main factors causing over/under-reactions to price changes. Being empirically verified, the changes show significantly stronger impact on investors' decision-making attitude. 
Most researchers, like DeBondt \& Thaler (1985) attempted to convince that news of price changes create a state of over-reaction on investors, whereas Lai (2001) even witnessed that under-reaction in similar news of price changes also set a shocking impact on their activities. Gradually, investors consider applying various other trading strategies towards profitable investment. Waweru et al. (2008) eventually concluded to prove that proper information in market strategy impacts highly on decision making by investors and this inclines them to divert towards most popular profitable stocks and other attractively prolific activities. Barber \& Odean (2000) consequently emphasized on investors strong and serious acquaintance towards profitable activities in stock markets, wherein their attentions are diverted instantly, without knowing whether these investments will produce good performance and reliable results in future. Odean (1998) explored and evolved amazing results to show that many investors trade abundantly due to 'over-confidence' and rely completely on market information, quality of the stocks and markets, with their prior decision making for investments. Odean (1999) stated that usually investors prefer to buy stock, which experienced higher changes within past two years, instead of selling those that claimed no price changes. However, Waweru et al. (2008) indicated that changes in stock prices place significant impressions on investors' behavior at some level, with the passage of time.

\section{Herding effect}

As the word 'herding' depicts, it is quite clear that 'Herding Effects' in financial markets express to identify behavior of investors to trail on the path and follow actions of their contemporary traders. Many practitioners usually intend to carefully look into the existence of herding aspects, as more reliance on collective information, instead of information from other sources. It may result in unstable and varied price deviations in the securities attained from fundamental values. Therefore, many chances for profitable investments may currently be lost and may provide significant impact in future. Similarly, academic researchers have also paid attention with keen interest towards herding effects, because its influence on changes in stock prices could be attributed to risks and return models, and could obviously impact the concept of assets pricing theories (Tan, Chiang, Mason \& Nelling,2008).

The investors make decisions regarding investment in security markets about selling or purchasing stock under the herding theory, along with decisions of masses. On the contrary, well informed and rational investors have no intentions to follow the masses, as it makes the markets to run efficiently. In contrast, herding causes some state of chaos towards inefficient markets, showing speculative bubbles for its recognition. To be more precise, herding investors tend to act generally as pre-historic investors, who had inadequate knowledge of their surroundings and to provide information, support and security to each other, gathered together in small groups (Caparrelli et al., 2004). They also proposed to argue that investors impressed by effects of herding trend move in similar flows with other investors when stock prices change. Another statement by Waweru et al. (2008) explained that most investors may look into incorrect estimates of stock returns in price changes, which causes inappropriate decision-making by the investors. since best stock selection depends on their preferences.

The investors running in routine momentum usually prefer well-performing stocks during recent periods, whereas rational investors prefer to sell the past losing stock, which provide postponement

ISSN: 2005-4289 IJDRC 
in taxes. The behavioral investors, on the other hand, prefer to sell their past winning stocks in order to meet the losses occurred during decisions of their stock trading (Waweru et al., 2008). The previous trends had been well explored in stocks that showed impact in investors' behavior of decision-making at certain levels (Waweru et al. 2008). As such, investors carefully conceptualize past-gone trends, prior to any decision for any investment, through technical methods. Several other elements that influence herding attitude of investors exist, for example, like volume of investment, overconfidence, etc. As a matter of fact, more confident investors rely more on private information for their investment decisions and apparently seem less interested in their behavior under herding theory.

The investors, who invest with larger amount of capital for their investments, usually intend to try in following the paths of other investors in order to curtail minimum risks. Preference for the herding aspect largely depends on their types and nature of investors. Their tendency to go in line with other investors to decide for investments is found more among individual investors, than as existent in other type of investors (Goodfellow, Bohl \& Gebka, 2009). Although, attempts to conclude decisions of buying and selling are well influenced by decisions of others investors, herding theory assists them in evolving an aversion attitude in regretting for earlier actions (Waweru et al., 2008). However, similar conclusions also hold in institutional investors in other decisions, as well but differ with individual investors. This statement emerged in contrast to the earlier argument mentioned above, that individual investors are more attentive to herding in investing than the investors otherwise.

\section{Methodology}

Since all individual investors in the Pakistan Stock markets have been included in the study undertaken through a survey, carried out by using the convenience sampling method, consisting of 193 respondents in the sample. With minor changes and some modifications, the structural questionnaire adopted earlier by Al-Tamimi (2005) was applied by using a 6-point Likert scale. The respective 6-points in the scale are: "extremely disagree, highly disagree, somewhat disagree, somewhat agree, highly agree, and extremely agree", presented in ascending order. The questionnaires were distributed online, with specific purposes, through managers of brokerage firms of Pakistan Stock Exchange being held responsible to send randomly to investors (respondents). The time constraints compelled us to select only individual investors in the study. Out of 193 questionnaires distributed to the respondents, only 167 questionnaires were found to be valid, being complete in every respect were received back for analyzing of the study. The questionnaires with 19 items pertained to theories of behavioral finance that influence factors relevant to decision-making aspects of investors, (Waweru et al., 2008). Based on this questionnaire, the most important items and most critical and vital factors will be identified accordingly.

By using Cronbach's Alpha scale, the valid questionnaires were presented for appropriate reliability tests. When combined construct validity coefficient is applied, then Cronbach's Alpha must exceed 0.7. Only then the scale is undoubtedly considered to be valid, correct and reliable (Ranganathan\& Henley, 2008; Arteaga-Ortiz \& Fernandez-Ortiz, 2010). According to our test results, overall Cronbach's alpha stood at 0.814 , whereas individually, it showed figures as 0.748 , 0.770, 0.641, and 0.630 for the four factors namely, Herding, Prospect, Market and Heuristic, 
respectively. Cronbach's alpha shows that these factors are reliable, since its resulting figure $(\alpha=$ $0.814)$ exceeds the minimum level of acceptability. There is also a clear indication that mean and standard deviations of all the four factors, which influence the behavior of investors in Pakistan Stock Exchange.

The impact of various levels of behavioral variables in investment decisions are estimated by the simple calculation of mean value of each determinant. Since we have used the 6-point scales to calculate and measure their impact levels, the values of mean are decided accordingly, on the basis of the following existing rules (Ngoc, 2014).

- Mean values less than 2 shows that variables have very low impacts

- Mean values between 2 to 3 shows that the variables have low impacts

- Mean values between 3 to 4 shows that the variables have moderate impacts

- Mean values between 4 to 5 shows that the variables have high impacts, and

- Mean values more than 5 shows that the variables have very high impacts.

\section{Results and Analysis}

As mentioned earlier, the main aim of the study was to explore and determine all important factors, which intend to influence investment decisions of investors, during the COVID-19 pandemic crises. Initially, all 19 factors affected the decisions of investors in Pakistan Stock Exchange, based on the behavioral dimensions, and are shown in Table-1. Table 2 shows that only 10 factors from among all the 19 factors, affects investment at highest levels, during COVID-19. It is also depicted in Table - 1 that in the dimensions of herding effects theory, "Brokers' recommendations" show the highest impact on investors' decisions, whereas within prospect theory's dimension, "get rich quick" had been allocated highest impact. Similarly, within the dimensions of market factors, the "Past performance of the firm's stock" shows highest impact accordingly, and within heuristic theory dimensions, highest impact in "Gut feelings on the economy" is presented in the Pakistan Stock Exchange markets with regards to investors' behavior. However, most vital factors influencing investors' decision making in Pakistan Stock Exchange markets with mean and standard deviations are enlisted below in adequate order of serious vitality and importance, as follows:

Get rich Quick $(M=4.81, S D=1.08)$, Loss Aversion $(M=4.67, S D=1.14)$,

Gut feelings on the economy $(M=4.51, S D=1.06)$, Fear of losing $(M=4.45$,

$S D=1.19)$, Expected corporate earnings $(M=4.41, S D=1.04)$, Expected

Dividends $(M=4.37, S D=1.12)$, Past performance of the firm's stock

$(M=4.23, S D=1.14)$, Brokers' recommendations $(M=4.18, S D=1.16)$,

Recommendations of family/friends $(M=4.10, S D=1.13)$ and, Opinions of

the firm's majority stockholders $(M=4.09, S D=1.10)$.

\section{Table 1. Factors affecting on investors" Behavior}

ISSN: 2005-4289 IJDRC 


\begin{tabular}{|l|l|l|l|}
\hline Factors & Variables & Mean & Std. Deviation \\
\hline \multirow{5}{*}{ Herding } & Broker recommendation & 4.18 & 1.16 \\
\cline { 2 - 4 } & Family/friend recommendation & 4.10 & 1.13 \\
\cline { 2 - 4 } & $\begin{array}{l}\text { Opinions of the firm's majority } \\
\text { stockholders }\end{array}$ & 4.09 & 1.10 \\
\hline Market & Fear of losing & 4.45 & 1.19 \\
\cline { 2 - 4 } & Loss Aversion & 4.67 & 1.11 \\
\cline { 2 - 4 } & Get rich Quick & 4.81 & 1.08 \\
\hline & Reputation of the firm & 3.32 & 1.03 \\
\cline { 2 - 4 } & Stock Marketability & 3.49 & 1.21 \\
\cline { 2 - 4 } & Past performance of the firm's stock & 4.23 & 1.14 \\
\cline { 2 - 4 } & $\begin{array}{l}\text { Government share holdings in the } \\
\text { company }\end{array}$ & 3.89 & 1.07 \\
\cline { 2 - 4 } & $\begin{array}{l}\text { Information obtained from the } \\
\text { internet }\end{array}$ & 3.73 & 1.21 \\
\cline { 2 - 4 } & Fluctuation in the stock index & 3.61 & 1.29 \\
\cline { 2 - 4 } & $\begin{array}{l}\text { Coverage in the press } \\
\text { Statements from government officials }\end{array}$ & 3.19 & 1.31 \\
\hline & Current economic indicators & 3.17 & 1.24 \\
\hline & $\begin{array}{l}\text { Recent price movement in a firm's } \\
\text { stock }\end{array}$ & 3.13 & 1.09 \\
\cline { 2 - 4 } & Rumors & 3.49 & 1.31 \\
\hline \multirow{5}{*}{ Heuristic } & Gut feeling on the economy & 4.51 & 1.06 \\
\hline & Expected corporate earnings & 4.41 & 1.04 \\
\hline & Expected Dividends & 1.12 \\
\hline
\end{tabular}

Table 2. Most influencing factors affecting on Investors' Behavior

\begin{tabular}{|l|l|l|l|l|}
\hline Ranking & Dimension & Variables & Mean & $\begin{array}{l}\text { Std. } \\
\text { Deviation }\end{array}$ \\
\hline 1 & Prospect & Get rich Quick & 4.81 & 1.08 \\
\hline 2 & Prospect & Loss Aversion & 4.67 & 1.11 \\
\hline 3 & Heuristic & Gut feeling on the economy & 4.51 & 1.06 \\
\hline 4 & Prospect & Fear of losing & 4.45 & 1.19 \\
\hline 5 & Heuristic & Expected corporate earnings & 4.41 & 1.04 \\
\hline 6 & Heuristic & Expected Dividends & 4.37 & 1.12 \\
\hline 7 & Market & Past performance of the firm's stock & 4.23 & 1.14 \\
\hline 8 & Herding & Broker recommendation & 4.18 & 1.16 \\
\hline 9 & Herding & Family/friend recommendation & 4.10 & 1.13 \\
\hline 10 & Herding & Opinions of the firm's majority stockholders & 4.09 & 1.10 \\
\hline
\end{tabular}


It is quite interesting to observe from Table 2 that most impressive and influencing variables could be categorized in wealth maximization criteria, such as "get rich quick" and "loss aversion", and obviously consistent with the findings of similar and parallel studies undertaken in some other countries (Merikas \& Pasand, 2003; Al- Tamimi, 2005). Three more factors, namely, "expected corporate earnings", "expected dividends" and "past performance of the firm's stock", could also be categorized under the wealth maximization criteria, since these factors significantly affected the Pakistani investors' behavior. These three factors are ranked at numbers 5, 6 and 7, respectively. In terms of loss aversion, results showed that investors had been more risk averse, during the COVID-19 crises so far. Since successful investments encourage investors, they consider risk aversion reactions to be normal, but the fear of losses obviously encircles them with deep depressions. However, averting losses are not often considered as feasible strategies, as the principle of "higher risks, higher returns", is always quite considerate (Ngoc, 2014). Similarly, Odean (1998) also argued that loss aversion produces unreliable decisions, and accordingly influence their investment aspects.

The results further suggest that investors in stock markets are quite confident in taking appropriate and effective decisions when deciding to plan for any investments. In Pakistan, they confide in their skills and knowledge, since three important factors, viz., Gut feeling on the economy", "Expected corporate earnings", and "Expected Dividends", strongly influence the investors' behavior. These findings are consistent with some studies undertaken earlier so as to clearly suggest the facts that investors assume with sincere belief that skills and knowledge could outperform market activities (Allen \& Evans, 2005; and Gervais, Simon \& Odean, 2001).

Moreover, Yates et al. (1997) attempted to confirm that most of the Asian nations are more prone to overconfidence in comparison to American and European investors. The findings of Ngoc (2014) completely opposed the above results and argued that in Vietnam, at Ho Chi Minh Stock Exchange, investors showed lesser confidence in making effective decisions for their investments. The author further attempted to articulate that two schools exist to forecast decision making in investments for the prices of stocks. The first one considers current prices to predict prices in future, whereas second school do not consider to forecast with the current prices. Furthermore, the factor regarding "Past performance of the firm's stock" influencing investors' behavior, very clearly depicts that individuals carefully tend to verify information regarding past trends of stocks and their price changes before investment activities. The result of our study is consistent with the previous study (Ngoc, 2014).

The results provide a strong support to the findings of some previous researchers (Farber, Nguyen \& Vuong, 2006; Tran ,2007), who suggested that effects of herding theory in Vietnam stock markets evolved strong and positive returns therein. Whereas, Ngoc (2014) argued that herding at moderate level in Vietnam stock market had been strong because of its ten-years long existence and running. By now investors had acquired sufficient knowledge and skills from different sources before making investment decisions. The results also demonstrated that most variables within Market dimension have moderate effect on investors' behavior it may be linked to the lack of training and education to respondents. Hence, understanding the importance of information on market price movement and vitality of technical analysis in forecasting is necessarily required. The investors in Pakistan Stock market wanted wealth maximization during COVID-19 but also

ISSN: 2005-4289 IJDRC 
had fears of losses and preferred loss aversion. Eventually, investors are compelled to take investment decisions based on their 'gut feelings', and 'recommendations of Brokers, Family/friend', and 'Opinion of firm's majority stockholders'.

\section{Conclusion}

This study attempts to explore the impact levels in those factors which influence individual investors' decisions in Pakistan stock market, during COVID-19 crises. These factors are grouped into four categories, viz., Herding effects, Market factors, Prospect theory, and Heuristic theory. Within the Herding dimension, most influencing variables are "recommendations of Brokers and Family/Friends and Opinions of majority shareholders". Similarly, Prospect dimension include "Get rich Quick, Loss Aversion" and "Fear of losing". Within Market factor dimension "Past performance of the firm's stock" only shows highest influence on investors' behavior and other market variables. Heuristics dimension consist of "Gutfeeling on the economy, expected corporate earnings" and "Expected Dividends".

The findings suggest that individual investors at the Pakistan stock market are confident to make good use of their knowledge and skills in critical conditions to attain more profitable outcome from their investments. During uncertain conditions, overconfidence provides an advantageous boost for investors to wrap up unexpected and difficult activities and helps in forecasting trends. The overconfident traders underestimate the risks related to active stock investments, causing repeated losses. They are advised to use overconfidence in appropriate ways, with manageable, clever and suitable intellect. Due to lack of information individual investors must select able advisers, since their guidance and assistance would limit the risks and increase opportunities for better profitable returns from their investments. We assure confidently that this study would be useful for individual investors, investment managers, and policy makers in practical terms. To be more precise, all researchers would understand the individual investors' behavior during a pandemic and formulate appropriate strategies for Pakistan stock market's growth. To confirm the findings of this research, it is necessarily required to undertake further research studies with even larger sample size and multiple diversities of respondents, including institutional investors, as well.

\section{References}

1. Anjum, S. (2020). Impact of market anomalies on stock exchange: a comparative study of KSE and PSX. Future Business Journal, 6(1), 1-11.

2. Aziz, B. \& Khan, A. (2016) Behavioural factors influencing individual investor's investment

3. decision and performance evidence from Pakistan stock exchange. International Journal of Research in Finance and Marketing, (IJRFM), 6(7), 74-86.

4. Al-Tamimi, H. A. H. (2005). Factors Influencing Individual Investors Behaviour: An Empirical study of the UAE Financial Markets, IBRC Athens, Aryan Hellas Limited.

5. Arteaga-Ortiz, J., \& Fernández-Ortiz, R. (2010). Why don't we use the same export barrier measurement scale? An empirical analysis in small and medium-sized enterprises. Journal of Small Business Management, 48(3), 395-420.

6. Allen, D. W., \& Evans, A. D. (2005). Bidding and overconfidence in experimenting financial markets. Journal of Behavioral Finance, 6(3), 8-120. 
7. Balooch, F.(2020). Pakistan's Stock Market More Likely to Outperform Post Covid. Samaa. Tv.

8. https://www.samaa.tv/opinion/2020/06/pakistans-stock-market-more-likely-tooutperform-post-covid/

9. Barber, B. M., \& Odean, T. (2001). Boys will be boys: Gender, overconfidence, and common stock investment. The quarterly journal of economics, 116(1), 261-292.

10. Barberis, N., \& Huang, M. (2001). Mental Accounting, Loss Aversion, and Individual Stock Returns. The Journal of Finance, 56(4), 1247-1292.

11. Barberis, N., \& Thaler, R. (2003). A survey of behavioral finance. In Constantinides, G., Harris,

12. M., \& Stulz, R. (Eds.), Handbook of the Economics of Finance. Amsterdam: NorthHolland.

13. Barber, B.M. and Odean, T. (2000). Trading is hazardous to your wealth: the common

14. stock investment performance of individual investors. Journal of Finance, 55 (2), $773-$ 806.

15. Caparrelli, F. D., Arcangelis, A. M., \& Cassuto, A. (2004). Herding in the Italian stock market: a case of behavioral finance. Journal of Behavioral Finance, 5(4), 222-230.

16. Croushore, D. (2006). Money and banking: a policy-oriented approach. Cengage learning.

17. DeBondt, W.F.M. and Thaler, R. (1985). Does the stock market overreact?. Journal of Finance, 40 (3), 793-805.

18. DeBondt, W. F. M., \& Thaler, R. H. (1995). Financial Decision-Making in Markets and Firms: A Behavioral Perspective. Handbooks in Operations Research and Management Science, 9(13), 385-410.

19. Fernandez, V. (2006). The impact of major global events on volatility shifts: Evidence from the Asian crisis and 9/11. Economic Systems, 30(1), 79-97.

20. Fromlet, H. (2001). Behavioral finance-theory and practical application: Systematic analysis of departures from the homo oeconomicus paradigm are essential for realistic financial research and analysis. Business economics, 63-69.

21. Filbeck, G., Hatfield, P., \& Horvath, P. (2005). Risk aversion and personality type. Journal of Behavioral Finance, 6(4), 170-180.

22. Farber, A., Nguyen, V. N., \& Vuong, Q. H. (2006). Policy impacts on Vietnam stock markets: a case of anomalies and disequilibria 2000-2006 (No. 06-005. RS). ULB-Universite Libre de Bruxelles.

23. Goodfellow, C., Bohl, M. T., \& Gebka, B. (2009). Together we invest? Individual and institutional investors' trading behaviour in Poland. International Review of Financial Analysis, 18(4), 212-221.

24. Gervais, S., Simon, H. and Odean, T. (2001). Learning to be overconfident. The Review of

25. Financial Studies, 14 (1), 1-27.

26. Kishore, R. (2004). Theory of behavioural finance and its application to property market: a change in paradigm. Australian Property Journal, 38(2), 105.

27. Kahneman, D., \& Tversky, A. (1979). Prospect theory: an analysis of decision-making under risk. Econometrica, 47(2), 263-291. http://dx.doi.org/10.2307/1914185

28. Kazmi, S. (2020). Coronavirus specter strikes PSX, KSE-100 index down 5.6\%. Pakistan Gulf \& 
29. Economist Magazine.https://www.pakistangulfeconomist.com/2020/03/09/stock-watch-9$\underline{10-20 /}$

30. Lai, M. (2001). Are Malaysian investors rational? Journal of Psychology and Financial Markets, 2(4), 210-215.

31. Lehenkari, M., \& Perttunen, J. (2004). Holding onto the losers: finish evidence. The Journal of behavioral Finance, 5(2), 116-126.

32. Merikas, A., \& Prasad, D. (2003). Factors influencing Greek investor behavior on the Athens stock exchange. Journal of Business, 66(1), 1-20.

33. Ngoc, L. T. B. (2014). Behavior pattern of individual investors in stock market. International Journal of Business and Management, 9(1), 1.

34. 'Oberlechner, T., \& Osler, C. L. (2008). Overconfidence in currency markets. Available at SSRN 1108787.

35. Odean, T. (1998). Volume, volatility, price and profit when all trades are above average. Journal of Finance, 53(6), 1887-1934.

36. Odean, T. (1999). Do investors trade too much? American Economic Review, 89(5), 12791298.

37. Plous, S., 1993. The psychology of judgment and decision making. McGraw-Hill, New York.

38. Ritter, J. R. (2003). Behavioral Finance. Pacific-Basin Finance Journal, 11 (4), 429-437.

39. Ranganathan, S. K., \& Henley, W. H. (2008). Determinants of charitable donation intentions: a structural equation model. International journal of nonprofit and voluntary sector marketing, 13(1), 1-11.

40. Seven, U., \& Yilmaz, F. (2020). World Equity Markets and COVID-19: Immediate Response and Recovery Prospects (No. 100987). University Library of Munich, Germany.

41. Samuel, C. (1996). Stock market and investment: the signalling role of the market. World Bank, Operations Policy Department, Operations Policy Group.

42. Sabir, S. A., Mohammad, H. B., \& Shahar, H. B. K. (2019). The role of overconfidence and past investment experience in herding behaviour with a moderating effect of financial literacy: evidence from Pakistan stock exchange. Asian Economic and Financial Review, 9(4), 480.

43. Tvede, L. (1999). The psychology of finance, Wiley, New York.

44. Tversky, A., \& Kahneman, D. (1981). Judgments of and by representativeness (No. TRStanford University Department of Psychology.

45. Tan, L., Chiang, T. C., Mason, J. R., \& Nelling, E. (2008). Herding behavior in Chinese stock markets: An

46. examination of A and B shares. Pacific-Basin Finance Journal, 16(1-2), 61-77.

47. Tran, V. H. (2007). Price limit regulation and herd behavior in Vietnamese stock market. Discussion paper No.139, Kyoto University

48. Waweru, N. M., Munyoki, E., \& Uliana, E. (2008). The effects of behavioral factors in investment

49. decision-making: a survey of institutional investors operating at the Nairobi Stock Exchange. International Journal of Business and Emerging Markets, 1(1), 24-41. 
50. Waweru, L. M., Kabiru, E. W., Mbithi, J. N., \& Some, E. S. (2003). Health status and health

51. seeking behaviour of the elderly persons in Dagoretti division, Nairobi. East African medical journal, 80(2), 63-67.

52. Yates, J. F., Lee, J., \& Bush, J. G. (1997). General knowledge overconfidence: crossnational

53. variations, response style, and "reality". Organizational Behavior and Human Decision Processes, 70(2), 87-94. 